\title{
Twitter Usage Practices of Digital Game Brands
}

\author{
Fatih Söğüt (Asst. Prof. Dr.)
}

iD Kırklareli University Vocational School of Social Sciences

fatih.sogut@klu.edu.tr

Date Received: 19.02.2021

Date Accepted: 31.05 .2021

Date Published: 30.07.2021

https://doi.org/10.17680/erciyesiletisim.883390

\section{Abstract}

Social media is a platform through which brands actively communicate with consumers. By using social media, brands can communicate with consumers regardless of time and place. The purpose of this study is to reveal how Twitter, a popular social media tool, is used by digital game brands. In the study, Sony PlayStation, Microsoft Xbox, and Ubisoft, the most followed digital game brands by Twitter users in the world, were selected as sample brands. The tweets published by the selected brands in three months between October 1, 2020 and December 31, 2020 were analysed using content analysis method. According to the results of the research, Sony PlayStation is the most followed digital game brand on Twitter. All three brands shared messages to encourage more sales and for promotion purposes. It was observed that the messages shared by these three brands were mostly in the form of direct tweets. It has been observed that the messages shared by Microsoft Xbox and Sony PlayStation mostly contain URLs and all three brands adopt a one-way communication style. Looking at the findings in general, it can be said that Twitter plays an important role in brand communication for digital game brands.

Keywords: Communication, Brand Communication, Twitter, Microsoft Xbox, Ubisoft, Sony PlayStation. 


\title{
Dijital Oyun Markalarının Twitter Kullanım Pratikleri
}

\author{
Fatih Söğüt (Dr. Öğr. Üyesi)
}

iD Kırklareli Üniversitesi Sosyal Bilimler Meslek Yüksek Okulu fatih.sogut@klu.edu.tr

Başvuru Tarihi: 19.02.2021

Yayına Kabul Tarihi: 31.05.2021

Yayınlanma Tarihi: 30.07.2021

https://doi.org/10.17680/erciyesiletisim. 883390

\section{Öz}

Sosyal medya markaların tüketicilerle aktif olarak iletişim kurdukları bir alandır. Sosyal medya kullanarak markalar tüketicilerle zaman ve mekândan bağımsız olarak iletişim kurabilmektedirler. Bu çalışmanın amacı popüler bir sosyal medya aracı olan Twitter'ın dijital oyun markaları tarafından nasıl kullanıldığını ortaya çıkarmaktır. Çalışmada, dünyada Twitter üzerinden kullanıcılar tarafından en çok takip edilen dijital oyun markaları olan, Sony Playstation, Microsoft Xbox ve Ubisoft örnek markalar olarak belirlenmiștir. Belirlenen markaların 1 Ekim 2020 ile 31 Aralık 2020 tarihleri arasını kapsayan üç aylık dönemde yayınladıkları tweetler, içerik analizi yöntemi ile incelenmiştir. Araştırma sonuçlarına göre, Twitter'da en fazla takip edilen dijital oyun markası Sony Playstation'dır. Üç marka da daha çok satışı teşvik etmek ve tanıtım amacı ile iletiler paylaşmışlardır. Üç markanın da paylaştığı iletilerin daha çok doğrudan tweet gönderimi biçiminde olmuştur. Microsoft Xbox ve Sony Playsation'ın paylaştıkları iletilerin daha çok URL içerdiğini ve üç markanın da ağırlıklı olarak tek yönlü iletişim biçimini benimsedikleri görülmüştür. Bulgulara genel olarak bakıldığında, dijital oyun markaları için Twitter'ın marka iletişimi açısından önemli bir rol üstlendiği söylenebilir.

Anahtar Kelimeler: İletişim, Marka İletişimi, Twitter, Microsoft Xbox, Ubisoft, Sony PlayStation. 


\section{Introduction}

Today, finalizing the popularity of classical media; social media is defined as online applications that develop independently of each other and allow users to reflect and share their own content with others. As a matter of fact, there is a mutual interaction between users and sharers in this kind of media based on technological developments, and the basis of this interaction is the developments in technology and the development of Web 2.0 technology.

Social media, especially in recent years, has become an important brand communication channel for brands with the increasing internet use of the consumers and the increasing time they spend on social media channels. In the literature review for digital games and brand communication, it has been seen that studies have been usually conducted in topics like in-game advertising applications (Nelson, 2002), product placement in digital games (Glass, 2007), digital games and brand awareness (Martí-Parreño, Bermejo-Berros, \& Aldás-Manzano, 2017). In this context, this study will make an important contribution to the digital gaming literature. Listed as social media channels; Thanks to blogs, microblogs, social networks, and forums, brands can address their customers through many channels. Similarly, individuals now listen to blogger suggestions and review links on social networks before making a decision. For this reason, social media is a very important platform for brand experts and marketers. It is possible for brands to reach their target audience, their usage habits, interests, complaints, needs, in short, anything they are looking for via social media.

In this study, which was conducted to evaluate social media in terms of brand communication in general, the functions of social media in brand communication were also discussed. In the research part of the study, Twitter was selected as the medium for evaluating the use of social media in brand communication. The tweets of Sony PlayStation, Microsoft Xbox, and Ubisoft, which are the most followed digital game brands on Twitter, during three months between October 1, 2020 and December 31, 2020 were examined.

\section{The Concept of Brand Communication}

Brand communication serves the functions of providing information about the brand, making the brand known, and creating meanings and associations that will distinguish the brand from other brands to make it more attractive (Feldwick, 2003, p. 140). Communication, beyond merely being a means of conveying a message to the environment, is a process in which the meaning of the transmitted message is formed and recognized. Communication is an inseparable and integral part of the life experience; therefore, symbolic meanings occur with the participation of consumers and marketing experts in the communication process (Firat \& Dholakia, 2006, pp. 145-146). The opinions of the companies about themselves and the main image they want to create in the eyes of the society are realized through communication strategies (Mattelart, 1995, pp. 266267). Especially the competition that increases with globalization discourses pushes businesses into seeking new strategic games in the war of market share, namely seeking global domination (Kitchen \& Schultz, 2003, p. 67). Therefore, companies can respond to global attacks with unconventional management and thinking structure by using the brand as a sustainable communication method (Papatya, 2006, p. 45). In this respect, the brand, as a special name or sign that serves to introduce any object and distinguish it from similar ones, is considered a means of establishing an emotional and conceptual 
bond with consumers (Gandini, 2016; Stephen, 2016; Belk, 2013; Labrecque, Ereni, \& Milne, 2011). When the change in the position of brands in our lives and the way they communicate is evaluated within the framework of consumption culture, development of digital technologies, and global economic systems, new approaches emerge in the context of offering an experience, enabling interactivity, creating pools of ideas, emotions, and thoughts through storytelling, and meeting the desire, need, or demand for belonging.

Brands work as a kind of widespread administrative tools that manage or program the day-to-day life. As a kind of virtual real estate, the brand occupies a valuable place in the mind of the consumer. This place has value to the extent that it can be a source of added value and profitability, to the extent that it can provide a brand interaction that fits and covers exactly what the consumer wants to do with the brand (Arvidsson, 2006, pp. 6-8). Within the scope of brand communication, the company tries to establish a relationship with its stakeholders and create a positive image of the brand.

Brand communication is the integration of all communication efforts that businesses plan in order to achieve their goals and implement their strategies to achieve their goals. For companies, brand communication is a holistic communication strategy delivering a message to the target audience via public relations, direct marketing, personal sales, sales development, product placement, and advertising activities (Tosun, 2010, pp. 192-193). For a successful brand communication, information about the sole value the brand offers, and the content must be clear, consistent, and continuous. There must be conformity and harmony between the promises of the brand, the communication tools, and messages (Arruda, 2009, pp. 409-410). Brand communication is a concept that creates shared meanings beyond delivering an informative message from the brand to the individual. Brand communication affects consumer behaviour with connotations that provide the right connection (Feldwick, 2003, p. 131). Codes and social conventions shared by consumers, as a system of indication that conveys brand promise and position, shape brand communication. In their studies examining the effect of brand communication on brand value, Grace and O'Cass revealed the importance of brand communication in creating a brand image that stimulates the emotions and thoughts of consumers and creating basic brand attitudes (2004, p. 453).

\section{The Role of Social Media in Brand Communication}

Today, it is increasingly important for brands to establish and maintain a relationship with the target audience. Online platforms are among the most important tools in establishing and maintaining the relationship between the brand and the target audience. The fact that social networks address a broad audience, and the specific characteristics of the addressed audience is known makes these platforms attractive for brand communication. The advantages of social media platforms for brand communication are listed as easy access to niche or large audiences, recognizing the target audience by creating interaction, and identifying their needs (Tosun, 2010, pp. 389-390). As the interactive structure of many social media platforms enables online discussions, brands have the opportunity to learn about the thoughts and feelings of the target audience about themselves and their competitors. While this information creates new opportunities for brands, it also provides easy access to different communities that may be interested in the brand (Davis, 2011, p. 391). In addition, social media platforms, unlike the traditional media, do not contain the obstacle of the threshold guards in the communication process of the brands, they ensure that the messages reach the target audience directly, and they provide the opportunity to receive feedback from the target audience (Özgen \& Elmasoğlu, 2016, p. 
199). Due to these reasons, many brands today have increased their investment in social media (Öztürk, 2015, p. 123). Through brand communication activities accomplish on social media, many different practices such as managing customer relations, promoting products and services, educating, and informing consumers, directing the target audience to purchasing behaviour can be carried out (Mangold \& Faulds, 2009, pp. 361-362). Social media pages, which are among the most important tools for brands to create meaningful, organic, and interactive content on social media, are defined as platforms established by businesses for brand communication and consumer interaction. Brand messages shared on social media are defined as the posts that businesses can produce easily, quickly, and frequently for free, and that allow followers/potential customers to receive daily notifications about a brand. While brand pages and posts allow the followers to follow the regular communication of the brand, it also makes it possible for consumers to interact with each other by providing the opportunity for likes, comments, and post (Lipsman, Mudd, Rich, \& Burch, 2012; Tafesse, 2015; Tafesse, 2016; Tafesse \& Wien, 2017; Zaglia, 2013).

Today, brands develop strategies specific to social media platforms to establish sustainable relationships. These strategies include positivity (making the relationship more enjoyable for target audiences), transparency (providing information on the nature of the organization and what it does), networking (forming networks or coalitions/forming public opinion with the same groups), sharing tasks (sharing projects or solving common interests), and reassurance (making the target audience believe that they are legitimate) (Ki \& Hon, 2006; Cho \& Huh, 2010). A lot of research has been conducted in the literature on the use of the content of businesses share on social media pages in terms of brand communication strategies and reflection of brand personality. The following examples can be given to these studies: The study in which de Vries et al. (2012) analysed the Facebook posts of 11 international brands through interaction, information, entertainment, liveliness variables, and the study in which Taecharungroj (2016), investigated Starbucks' use of Twitter based on content sharing categories of sharing information, emotional content, and directing to action. In addition, Vassollo et al. (2018), in the study examining the marketing strategies of 15 fast food and snack food brands on Instagram, analysed the posts of brands in two categories, informative and image-oriented. In this analysis, which also forms the basis of the research model of this study, different strategies such as celebrity use as sub-brand communication categories, sponsorship, interaction creation are also evaluated. In another study, Tafesse and Wien (2017), analysed the Facebook pages of brands considered successful according to the Interbrand Best Global Brand research. In this study, the researchers evaluated the brands on the basis of using different strategies in their posts such as using emotional, functional, and educational content, event announcement, customer relations, purposeful marketing activities, and special offer announcement. Wattanacharoensil and Schuckert (2015), on the other hand, analysed the brand communication strategies used in the Facebook posts of airports through different categories such as airport atmosphere, location promotion, information updates, research and surveys, and event announcements. Özgen and Elmasoğlu (2016), in their research examining the use of social media for brand communication by airline companies in Turkey on Twitter, found that all three airlines share posts that encourage more sales, THY mostly uses plain texts in posts, while Pegasus Airlines and Anadolu Jet mostly use "url"s with the aim of establishing connectivity. These studies show that social media platforms are effectively used by companies operating in different sectors for strategic brand communication activities. 


\section{Digital Game Industry}

Today, production outputs towards digitalization in production and supply emerge in different forms. The closeness established between different platforms in communication platforms reveals structures that contain different cultural elements in order for the production and consumption channels to function properly. In addition, the original structures of the communication channel content create structures that complement each other in the consumption process. Digital games as a game genre emerged and continued to develop since the mid-1980s with concepts and cultural elements such as computer games, video games, and electronic games. However, the definition of digital games has been used frequently in the literature since the mid-2000s. There are all kinds of arcade games, computer games, console games, and mobile games that are different from each other in the definition of digital games (Binark \& Sütçü, 2008). Today's major cultural industry tools include the traditional media industries such as television, radio, books, newspapers, magazines, movies, and music, as well as new media industries such as internet and digital games. The most defining characteristic of such commodities is that these genres consist of different cultural codes and patterns. When communicationbased consumption processes are examined and these processes are evaluated in terms of the actors, it is necessary to draw attention to capitalist production relations. Indeed, the role of digital actors in reproducing capitalist production relations differs from traditional media audience discussions. At this point, Castells (2004), evaluating new media within the contexts of political economy, emphasizes the transformation of social and cultural production-consumption processes as the informationalization of society. Castells (2004)points out that digital actors are increasingly becoming the subject of cultural consumption and being seen as the object of commodification and reification processes. Digital games, which have become a cultural consumption tool, take place in capitalist production relations that keep increasing in economic activities in the transition from industrial societies to information societies. Changes in information and communication technologies also play an important role in digital games becoming a cultural consumption tool. The differences in the production processes of digital games have caused the games to be evaluated with different labor structures from the design process to the publishing process. It is possible to state that digital games, which have become a part of the capitalist consumption culture, are a final product that are paid for during consumption. Mosco (1988), defines this process as pay-per-use communities.

Although games have played an active role as a phenomenon throughout human history, they are now often identified with children or adolescents, especially boys (Iversen, 2016). However, digital games have become an integral part of daily life for people of all ages and genders in recent years. Bak et al. (2012)found that between 5\% and 12\% of the population over sixty years of age play digital games at least once a day in Norway, Sweden, and Denmark. This ratio corresponds to $18 \%$ to $29 \%$ of the total population of these countries. Similarly, Pratchett et al. (2005) found that around 30\% of the population over fifty years of age play digital games at least once or twice a week in the UK. While motivation of mental exercise and spending time underlie at the basis of the elderly's desire to play (Iversen, 2016), socialization, stress relief, and feeling strong form the basis of the desire to play in children and young people (Schor, 2004; Gros, 2007). It is estimated that approximately 1.5 billion people in the world actively played digital games in 2014 and the annual turnover of this market was approximately 42 billion dollars (Buluş \& Buluş, 2020, p. 3). In fact, digital games market grew well above the growth rates recorded in the global economy, with an average annual growth rate of over $8 \%$ globally 
between 1999 and 2014 (Cabras, et al., 2017). These significant quantitative increases in the digital game industry allow game developers to transform according to gamers' needs. Today, game developers determine the demographic information of their target customers and try to include new players in the market by designing games according to the wishes of the players.

\section{Method}

The main purpose of this study is to examine the use of social media networks for brand communication. It will be determined which sub-branches of marketing communication like advertising, direct sales and customer relations are used extensively by digital game brands. Accordingly, "Twitter," was chosen as the social media channel to be examined, which offers the opportunity to write texts with a maximum of 280 characters, called tweets. Twitter is a popular social network and microblogging site that is used quite frequently today. Twitter creates an ever-updated timeline of messages about life and news ranging from ideas to links and latest news, inviting users to answer the question "what are you up to?" Twitter is a platform that allows its users to select the Twitter accounts to "follow" and each of them to have their own "followers" (Marwick \& Boyd, 2016, pp. 114-115). According to a study conducted in 2020, the number of active Twitter users is over 340 million (https://datareportal.com/, 2020). When Turkey's 2020 Twitter report is reviewed, it is seen that the total number of users are up to 8.6 million (https:// digitalage.com/, 2020).

Social media network sites such as Twitter are among the channels that brands frequently use to communicate with their users. Brands are able to convey information about their companies, products, and campaigns through social networking sites, and establish a dialogical communication with their users. Twitter, which can be used to convey brand information or respond to comments, is thought to contribute to the formation of the brand image. Through Twitter, brand managers can understand not only what customers and potential consumers are talking about, but more importantly, how they express themselves through the words and phrases they use. With this data, better products, services, and communication messages can be designed. In addition, by creating labels called "hashtags" for branding events such as special offers, brand managers can encourage consumers to discuss and give feedback on a certain topic, manage the conversations of people who buy from their brand, identify opinion leaders in the target market by looking at the number of followers, and participate in discussions (Temporal, 2010, pp. 208-209).

The secondary aim in this study is to provide an evaluation of how brands use social media through Twitter and to contribute to the literature on the subject. In line with this goal, Sony Computer Entertainment, Ubisoft, Microsoft-Xbox Games companies operating in the digital game industry in the world were selected as the field of study within the scope of the research. These companies are among the 10 most valuable gaming companies in the forbes online website ${ }^{1}$.

The brands affiliated with these companies have been selected because they have the highest twitter followers among these most valuable gaming companies. When we look at the number of followers in the official Twitter accounts of these companies respectively, the Twitter account of PlayStation, Sony Computer Entertainment's biggest brand, has 20.6 million followers, while the number of followers of Xbox's Twitter account, which 
is the biggest brand of Microsoft in the digital game market, is 15.2 million. Finally, the number of followers of the Ubisoft company's Twitter account is 8.2 million.

The tweets published by the selected brands in the three-month period -October, November, and December- covering the period between October 1, 2020 and December 31,2020 , were selected randomly. Brands speed up their campaigns in autumn before winter starts. It is known that brands try to increase their prestige, number of users, and awareness by organizing interesting and creative campaigns, especially with the effect of New Year and Christmas celebrations in December.

Within the specified dates, the following accounts have been examined: @PlayStation, https://twitter.com/PlayStation for PlayStation brand, @Xbox, https://twitter.com/Xbox for Xbox brand, and @Ubisoft, https://twitter.com/Ubisoft for Ubisoft brand. A total of 2263 tweets in the Twitter accounts of all three brands were scanned with the backward scanning method in 1-30 January 2021 and evaluated by content analysis. According to Bilgin (2006, pp. 14-15), the content analysis method aims to reach some results beyond the information displayed, based on some quantitative or qualitative data. Content analysis is important in that it enables researchers to gain some logical information by inference about the message, channel, sender, and receiver of the message.

Based on the basic assumption that 'social media is effective in brand communication,' it was attempted to reveal how the most valuable digital game companies in the world use their Twitter accounts. Question categories were created by utilizing related studies on the use of social media (Bayraktutan, et al., 2013; Çetin \& Elmasoğlu, 2014; Özgen \& Elmasoğlu, 2016; Güz, Yegen, \& Yanık, 2016) Categorical analysis is one of the techniques used in content analysis method, and it involves grouping certain messages into various units. In order for meanings to be processed, messages must be encoded (Bilgin, 2006, p. 19). In this context, the following categories of questions were created to seek answers within the scope of the study.

1-What are the findings regarding the number of followers of digital game brands?

2-What are the findings regarding the tweet numbers of digital game brands?

3-What are the findings regarding the topics of tweets shared by digital game brands?

4-What are the findings regarding the language features of tweets shared by digital game brands?

5-What are the findings regarding the formal features of tweets shared by digital game brands?

The semantic relation between categories and data was checked in the validity and reliability phase. At this point, an academic expert in the field of communication afforded assistance. The matching made by the expert and the matching made by the researcher were compared. As the validity and reliability reference of the research, the formula of Miles and Huberman (1994, p. 64) Reliability = Agreement / (Agreement + Disagreement) was preferred. According to this formula, in terms of reliability, a result above $70 \%$ is sufficient in researches. A rate of $84 \%$ was found in the comparison made for this study.

\section{Findings}

In this section, the posts in Twitter accounts of brands have been evaluated by considering the number, subject, style, and direction of communication. 


\section{Examinations of Twitter Accounts of the Brands}

Table 1. Twitter Accounts of Brands

\begin{tabular}{|l|c|c|c|}
\hline Digital Game Brands & Number of Tweets & Number of Followers & Number of Brand Follows \\
\hline Sony PlayStation & 36.2 Thousand & 20.6 Million & 754 \\
\hline Microsoft Xbox & 270.9 Thousand & 15.2 Million & 16.000 \\
\hline Ubisoft & 41 Thousand & 8.2 Million & 627 \\
\hline
\end{tabular}

When the Twitter accounts of the world's biggest digital game brands are examined, it is seen that the most tweets belong to Xbox with 270 thousand posts. Ubisoft follows Xbox with 41 thousand tweets. PlayStation ranks third with 36 thousand tweets. When the number of followers of the brands is examined, PlayStation has the most number of followers with 20.6 million followers. The second brand is Xbox with 15.2 million. In third place is Ubisoft with 8.2 million followers.

When the number of people or institutions followed by the brands is examined, the number of people or institutions followed by Xbox is 16 thousand and the number of accounts followed by the PlayStation account is 754. The number of people or institutions that Ubisoft follows is 627. Among the accounts followed by Sony PlayStation are the accounts of brands from different sectors such as Burger King (@BurgerKing) and Nike Basketball (@nikebasketball). In addition, the accounts of many digital game producers are also followed. The Sony PlayStation twitter account also follows the accounts of the other two brands included in this research.

Like the PlayStation account, the Xbox twitter account follows many digital game brands. Xbox twitter account follows the corporate accounts of companies operating in many different fields, ranging from the airline industry (@AlaskaAir) to the cinema industry (@starwars). Other accounts of the Microsoft company that operate in different areas are also followed.

Looking at the Ubisoft brand's twitter account, it is seen that personal accounts are followed as well as corporate accounts. The accounts of important people working in the gaming industry are followed. For example, Matt Woomer (@MattWoomer), the general director of Blue Mammoth Games, and Ikumi Nakamura, the art director of popular games such as Ghostwire Tokyo, Bayonetta, account (@ nakamura193) are followed by Ubisoft.

Table 2. Total Number of Tweets by Months

\begin{tabular}{|l|c|c|c|c|c|c|}
\hline \multirow{2}{*}{ Digital Game Brands } & \multicolumn{2}{|c|}{ October } & \multicolumn{2}{c|}{ November } & \multicolumn{2}{c|}{ December } \\
\cline { 2 - 7 } & Number & \% & Number & \% & Number & $\%$ \\
\hline Sony Playstation & 411 & $\% 33,27$ & 401 & $\% 32,46$ & 423 & $\% 34,25$ \\
\hline Microsoft Xbox & 238 & $\% 29,91$ & 246 & $\% 30,90$ & 311 & $\% 39,11$ \\
\hline Ubisoft & 86 & $\% 36,9$ & 75 & $\% 32,18$ & 72 & $\% 30,90$ \\
\hline Total & 735 & $\% 32,47$ & 722 & $\% 31,90$ & 806 & $\% 35,63$ \\
\hline
\end{tabular}

The total number of tweets posted by the brands in the three-month period between October 1, 2020 and December 31, 2020 is 2263. Sony PlayStation posted a total of 1235 (54.57\%) tweets, 411 in October, 401 in November, and 423 in December. Xbox posted a total of 795 (35.13\%) tweets, 238 in October, 246 in November, and 311 in December. Ubisoft posted a total of 233 tweets (10.29\%), 86 in October, 75 in November, and 72 in December. When numerical data are evaluated, it is seen that Sony PlayStation, which has the highest number of followers, tweeted the most on Twitter in October, November, and December 2020. Sony PlayStation is followed by Xbox and Ubisoft, respectively. 
It is noteworthy that the brands tweeted the most in December. In November, the new generation game consoles of both PlayStation and Xbox were launched. Consequently, Twitter usage of these brands has increased in the context of sales and marketing activities. As the Ubisoft brand launched two big games (Assassin's Creed Valhalla and Immortals Fenyx Rising) in October and November, Twitter usage increased during these months in terms of sales and marketing as well.

\section{Examinations of the Subjects of the Messages in the Twitter Accounts of the Brands}

In this study, which examines the use of social media for brand communication, another topic is the subject contents of the tweets in the brand accounts. When the tweets of the examined accounts are evaluated in general, it is seen that brands generally share messages with the subjects of sales incentives, campaigns and promotions, information, news, special offers, events, corporate, and advice-requests.

Table 3. Distribution of Tweets by Subject

\begin{tabular}{|l|c|c|}
\hline Subjects & Number & \% \\
\hline Sales Incentive & 921 & $\% 40,69$ \\
\hline Campaigns and promotions & 274 & $\% 12,1$ \\
\hline Information & 11 & $\%, 48$ \\
\hline News & 155 & $\% 3,84$ \\
\hline Special offers & 808 & $\% 1,85$ \\
\hline Events & 42 & $\% 0,7$ \\
\hline Corporate & 16 & $\% 2,29$ \\
\hline Advice-requests & 52 & $\% 100$ \\
\hline Total & 2263 & $\%$ \\
\hline
\end{tabular}

When the rates of the posts are analysed in terms of subjects, in 921 (40.69\%) of the total 2263 tweets, the subject is related to "sales incentives." In Peltekoğlu's words $(2009$, p. 52), sales incentives are messages that aim to influence customers' purchasing decision at that moment. Sales incentive methods, which are carried out to achieve a temporary increase in sales, are becoming increasingly widespread in the marketing world. 808 (35.7\%) of the tweets consist of content for "promotional" purposes, evaluated within the scope of sales incentive activities. It is seen that $274(12.1 \%)$ of the tweets have a "campaign and special offer" content. 155 of them are "news" (6.84\%) content about customers or the institution. 11 of these tweets are "informative" $(0.48 \%), 42(1.85 \%)$ are about "event," and 16 of them are "institutional" news (0.7\%). Lastly, it is observed that $52(2.29 \%)$ of the tweets are messages containing "advice" and "requests."

Table 4. Subjects Shared by Sony PlayStation

\begin{tabular}{|l|c|c|c|c|c|c|c|c|}
\hline \multicolumn{2}{|c|}{ Subjects } & \multicolumn{2}{|c|}{ October } & \multicolumn{2}{c|}{ November } & \multicolumn{2}{c|}{ December } & \multicolumn{2}{c|}{ Total } \\
\cline { 2 - 10 } & Number & $\%$ & Number & $\%$ & Number & $\%$ & Number & $\%$ \\
\hline Sales Incentive & 124 & $\% 30,17$ & 115 & $\% 28,67$ & 134 & $\% 31,67$ & 373 & $\% 30,2$ \\
\hline $\begin{array}{l}\text { Campaigns and } \\
\text { promotions }\end{array}$ & 42 & $\% 10,2$ & 11 & $\% 2,74$ & 19 & $\% 4,49$ & 72 & $\% 5,82$ \\
\hline Information & 5 & $\% 1,2$ & 1 & $\% 0,24$ & 0 & $\% 0$ & 6 & $\% 0,48$ \\
\hline News & 30 & $\% 7,29$ & 84 & $\% 20,94$ & 16 & $\% 3,78$ & 130 & $\% 10,52$ \\
\hline Special offers & 190 & $\% 46,2$ & 177 & $\% 44,13$ & 215 & $\% 50,82$ & 582 & $\% 47,12$ \\
\hline
\end{tabular}




\begin{tabular}{|l|c|c|c|c|c|c|c|c|}
\hline \multicolumn{1}{|c|}{ Sony PlayStation } \\
\hline \multirow{2}{*}{ Subjects } & \multicolumn{2}{|c|}{ October } & \multicolumn{2}{c|}{ November } & \multicolumn{2}{c|}{ December } & \multicolumn{2}{c|}{ Total } \\
\cline { 2 - 10 } & Number & $\%$ & Number & $\%$ & Number & $\%$ & Number & $\%$ \\
\hline Events & 11 & $\% 2,6$ & 8 & $\% 1,99$ & 2 & $\% 0,47$ & 21 & $\% 1,7$ \\
\hline Corporate & 5 & $\% 1,2$ & 3 & $\% 0,74$ & 2 & $\% 0,47$ & 10 & $\% 0,80$ \\
\hline Advice-requests & 4 & $\% 0,97$ & 2 & $\% 0,49$ & 3 & $\% 0,70$ & 9 & $\% 0,72$ \\
\hline Total & 411 & $\% 100$ & 401 & $\% 100$ & 423 & $\% 100$ & 1235 & $\% 100$ \\
\hline
\end{tabular}

When the tweets of the Sony PlayStation in these three months are examined separately, $582(47.12 \%)$ of the total 1235 tweets posted by the brand are about promotion, 373 (30.2\%) are sales incentives, and $130(10.52 \%)$ are on news related subjects. The brand tweeted for promotion the most. The brand uses trailer videos frequently as a promotion strategy. Games are introduced to the followers with videos. For example, as seen in the tweet "Watch the new Elder Scrolls Online teaser, revealed last night at \#TheGameAwards" ${ }^{2}$ and "Purge the Wild West of monstrosities solo or with a gunslingin' co-op pal. Evil West comes to PlayStation next year. Watch the reveal trailer: https:// play.st/2LrWikf" ${ }^{3}$. The brand has tried to lead customers to buy their products by using elements such as curiosity, encouragement, and activation in its sales incentives posts. Such as "Sleigh some zombies in \#BlackOpsColdWar's new limited-time holiday Onslaught

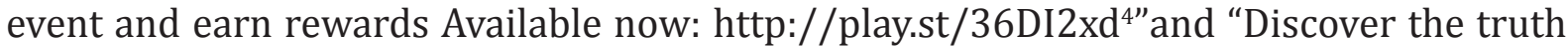
behind the first samurai in Nioh 2's third and final DLC expansion, coming December 175: https://play.st/2K8ZX5S ${ }^{5 "}$

After promotion and sales incentives, the most frequent subject in the brand's tweets is news. The brand shared the news of success and awards it received, with the followers. In particular, the games that were co-produced with Sony, which won the Game of the Year award, were highlighted. "Taking home 9 Trophies, including 7 Platinums, The Last of Us Part II was the biggest winner in PS Blog's reader-voted Game of the Year awards6: http:// play.st/3p5oLli Congratulations, @Naughty_Dog!" and "Congrats, @insomniacgames! Marvel's Spider-Man: Miles Morales was voted November's best new game by PS Blog readers: https://play.st/36DFkaH ${ }^{7 "}$ Also; In general, it has been observed that the brand organizes various promotions to promote sales; "Glide into Fortnite with the stylish Cloud Striker Outfit and Elevation Back Bling, free to PlayStation Plus members now :

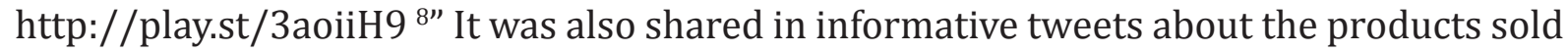
and the services provided: "SIE strives to ensure a high level of customer satisfaction, and we will begin to offer a full refund for all gamers who have purchased Cyberpunk 2077 via PlayStation Store and want a refund. Please visit the following link to initiate the refund : https://bit.ly/3h5VkpC ${ }^{9 "}$ As an activity, the Sony Playstation account shares interviews with people working in the gaming world with their followers; "Discover the origins of Nier's fictional Chaos Language in our interview with singer and lyricist Emi Evans : http://play.st/37sirHE ${ }^{10 ", ~ " T u n e ~ i n t o ~ J J J ' s ~ p o d c a s t ~ J u s t ~ t h e ~ F a c t s, ~ f e a t u r i n g ~ s p e c i a l ~}$ guest Danika Hart, where both hosts will give their viewpoints on the suits, gadgets and parkour style of \#MilesMorales. Marvel's Spider-Man: Miles Morales, available now for \#PS4 and \#PS5. \#BeGreater \#BeYourself ${ }^{11 "}$

As "Advice" and "Wish", the Sony Playstation account celebrates the Thanksgiving Day of its followers. "Make sure to mash the potatoes before they mash you. Happy Thanksgiving ${ }^{12 "}$ In another tweet, it advises its followers to vote for Game of the Year awards; "Get carried away by the journey of Season, revealed last night at \#TheGameAwards: https://play.st/39UQD0e ${ }^{13 "}$ 
Table 5. Subjects Shared by the Microsoft Xbox

\begin{tabular}{|l|c|c|c|c|c|c|c|c|}
\hline \multicolumn{7}{|c|}{ Microsoft Xbox } \\
\hline \multirow{2}{*}{ Subjects } & \multicolumn{2}{|c|}{ October } & \multicolumn{2}{c|}{ November } & \multicolumn{2}{c|}{ December } & \multicolumn{2}{c|}{ Total } \\
\cline { 2 - 11 } & Number & $\%$ & Number & $\%$ & Number & $\%$ & Number & $\%$ \\
\hline Sales Incentive & 100 & $\% 42,01$ & 122 & $\% 49,59$ & 177 & $\% 56,91$ & 399 & $\% 50,18$ \\
\hline $\begin{array}{l}\text { Campaigns and } \\
\text { promotions }\end{array}$ & 51 & $\% 21,42$ & 54 & $\% 21,95$ & 62 & $\% 19,93$ & 167 & $\% 21$ \\
\hline Information & 2 & $\% 0,84$ & 0 & $\% 0$ & 1 & $\% 0,32$ & 3 & $\% 0,37$ \\
\hline News & 7 & $\% 2,94$ & 5 & $\% 2,03$ & 8 & $\% 2,57$ & 20 & $\% 2,51$ \\
\hline Special offers & 42 & $\% 17,64$ & 47 & $\% 19,10$ & 57 & $\% 18,32$ & 146 & $\% 18,36$ \\
\hline Events & 10 & $\% 4,20$ & 5 & $\% 2,03$ & 3 & $\% 0,96$ & 18 & $\% 2,26$ \\
\hline Corporate & 2 & $\% 0,84$ & 0 & $\% 0$ & 1 & $\% 0,32$ & 3 & $\% 0,37$ \\
\hline Advice-requests & 24 & $\% 10,08$ & 13 & $\% 5,28$ & 2 & $\% 0,64$ & 39 & $\% 4,90$ \\
\hline Total & 238 & $\% 100$ & 246 & $\% 100$ & 311 & $\% 100$ & 795 & $\% 100$ \\
\hline
\end{tabular}

Of the 795 tweets shared by the Microsoft Xbox, 399 (50.18\%) were sales incentive, 167 (21\%) campaigns and promotions, $146(18.36 \%)$ publicity, 39 (\% 4.90) issues related to advice-wishes. The brand, as in the Sony Playstation, shared the most sales incentive. In its posts regarding sales incentive, the brand has made posts that will attract the attention of its followers about the games that are usually on the Xbox game console. For Example: "Looking for a holiday adventure like Rufus's? You can now select and fly Rufus and Sam's planes in Flight Simulator! We've also decked out 12 iconic landmarks around the world with festive holiday lights, ready for you to discover: https://msft.it/6017pXJpJ ${ }^{14 "}$ The Xbox brand shared the second most campaign and promotional announcements. In these posts, in-game gifts are presented to the players as well as gifts such as gamepads. For Example: "The coziest zombie apocalypse survivors you ever did see Find five holiday sweaters in your closet until January 2: http://xbx.lv/3h8N4VS ${ }^{15}$ ", "This is the way. Follow @Xbox and RT with \#TheMandalorianXboxSweepstakes for a chance to win controllers inspired by @TheMandalorian 16"

Microsoft Xbox, in third place, seems to share advice-wishes. This brand, unlike the other two brands, has been seen to include social responsibility shares in this category. For example: Using the \#COVID19Fund ${ }^{17}$ hashtag, followers are invited to donate to the World Health Organization. Yet another social responsibility sharing was made about breast cancer using the \#GamePink ${ }^{18}$ hashtag.

An approach that emphasizes the technical features and power of the new generation game consoles Xbox Series X and Xbox Series S, which went on sale in November, stands out in the posts made in the publicity category of the Microsoft Xbox twitter account. For Example: "Even though these beasts are mythological, you might start to think they're real. 4K Ultra HD and 60fps on Series X: https://xbx.lv/3gZIDMM ${ }^{19}$ ". A single share was found in the information category. In this post, an announcement was made to the followers regarding the return process of the Cyberpunk 2077 game released on Xbox consoles. In the corporate category, announcements about collaborating companies such as AMD and CD Projekt attract attention. In the activity category, the announcement of the game awards ceremony is made using the hashtag \# MicrosoftFlightSim \# TheGameAwards. 
Table 6. Subjects Shared by the Ubisoft

\begin{tabular}{|l|c|c|c|c|c|c|c|c|}
\hline \multirow{2}{*}{ Subjects } & \multicolumn{2}{|c|}{ October } & \multicolumn{2}{c|}{ November } & \multicolumn{2}{c|}{ December } & \multicolumn{2}{c|}{ Total } \\
\cline { 2 - 10 } & Number & $\%$ & Number & $\%$ & Number & $\%$ & Number & $\%$ \\
\hline Sales Incentive & 51 & $\% 59,30$ & 43 & $\% 57,33$ & 39 & $\% 54,16$ & 133 & $\% 42,91$ \\
\hline $\begin{array}{l}\text { Campaigns and } \\
\text { promotions }\end{array}$ & 10 & $\% 11,62$ & 14 & $\% 22,66$ & 11 & $\% 15,27$ & 35 & $\% 16,90$ \\
\hline Information & 1 & $\% 1,16$ & 0 & $\% 0$ & 1 & $\% 1,38$ & 2 & $\% 0,85$ \\
\hline News & 2 & $\% 2,32$ & 1 & $\% 1,33$ & 2 & $\% 2,77$ & 5 & $\% 2,14$ \\
\hline Special offers & 17 & $\% 19,76$ & 13 & $\% 17,33$ & 18 & $\% 24,99$ & 48 & $\% 20,60$ \\
\hline Events & 2 & $\% 2,32$ & 0 & $\% 0$ & 1 & $\% 1,38$ & 3 & $\% 1,28$ \\
\hline Corporate & 2 & $\% 2,32$ & 0 & $\% 0$ & 1 & $\% 1,38$ & 3 & $\% 1,28$ \\
\hline Advice-requests & 1 & $\% 1,16$ & 1 & $\% 1,33$ & 2 & $\% 2,77$ & 4 & $\% 1,71$ \\
\hline Total & 86 & $\% 100$ & 75 & $\% 100$ & 72 & $\% 100$ & 233 & $\% 100$ \\
\hline
\end{tabular}

When the tweets posted by the Ubisoft brand, which is the last brand examined within the scope of the research, are also examined; It was determined that 133 (42.91\%) of the total 233 tweets shared by the brand were sales incentive, $48(20.60 \%)$ were publicitiy and 35 $(16.90 \%)$ were about campaigns and promotions. The Ubisoft, as in the Sony Playstation and Microsoft Xbox, shared the most sales promotion purposes. The brand encourages players to buy digital games produced by the brand, usually with Christmas discounts and various special discounts on shares related to the purpose of promoting sales. For example: "Stuff your stocking with this season's holiday savings with up to $75 \%$ off on top Ubisoft titles like \#ImmortalsFenyxRising, \#JustDance2021, and \#MarioRabbids Kingdom Battle! Sale ends 12/31 at 11:59 PM PT ${ }^{20 "}$ and "Save up to 72\% on Anno 1800. Hurry, the deal is only available today at the @ubisoftstore ${ }^{21 "}$ as in your tweets. Second, the Ubisoft brand included publicity posts. In the publicitiy tweets, it is seen that new games are given priority. Immortals Fenyx Rising, Assassin's Creed Valhalla and Watch Dogs: Legion, which were released by Ubisoft in October-November and December, are intense. For example: "Begin your adventure with @FenyxRising ${ }^{22 "}$ and "It's Adventure Time! Kick some monsters' buns wearing Finn's outfit, ride a rainbow unicorn and let Jake fly on your side with the Adventure Time Character Pack, now available in Immortals Fenyx Rising ${ }^{23}$

In the campaign and promotion category, Ubisoft featured free games that will be given every day between 14-18 December 2020. This campaign, called Happy holidays, is given to the followers "1 free gift per day! From December 14 to December 18. Today's gift: free copy of Trials Rising Standard Edition game on Ubisoft Connect PC. " Announced with Tweet.

Ubisoft provided information to its followers about the Ubisoft corporate account, which started operating on the tik tok platform, in its corporate category; "Yes we're on Tiktok Yes we're launching with peaceful walking content https://tiktok.com/@ubisoft"

Ubisoft predominantly highlights the game awards ceremony in its news category. The nomination of the games belonging to Ubisoft in the contest was reported, especially in the posts. For example, "We are honored that Assassin's Creed Valhalla has been nominated for \#TheGameAwards for the following categories: Innovation in Accessibility Best Action/Adventure ${ }^{24 "}$ 
In the information category, Ubisoft has included two shares. The first of these shares is about the release date of the Prince of Persia game that the company is working on. The second one is related to the updated PC system requirements of Watch Dogs: Legion game.

In the activity category, Ubisoft shares live broadcast events attended by its own employees. For example, "Watch the Ubisoft News team today at 9AM PT for some brand-new Assassin's Creed Valhalla Gameplay. Game designer Jessica Maher joins the stream to shed some light on the settlement of Ravensthorpe, Valhalla's new combat mechanics, the return of social stealth, and much more ${ }^{25}$ " and "Today we unveiled \#UbisoftConnect, an all-new gaming hub designed to level up the player experience Meet Stephanie Perotti (VP of Online Services) and Charles Huteau (Creative Director on @UbisoftConnect) to learn more! 26"

Finally, in the category of advice and wishes, Ubisoft celebrates the new year of its followers with its tweets. For example, "Happy Holidays Run, jump and win free rewards with our holiday minigame!"7" tweet can be displayed.

\section{Investigations on the Format and Direction of the Messages in the Twitter Accounts of the Brands}

Table 7. Forms of Tweets

\begin{tabular}{|l|c|c|c|c|c|c|c|c|}
\hline \multirow{2}{*}{ Forms of Tweets } & \multicolumn{2}{|c|}{ Sony PlayStation } & \multicolumn{2}{|c|}{ Microsoft Xbox } & \multicolumn{2}{|c|}{ Ubisoft } & \multicolumn{2}{c|}{ Total } \\
\cline { 2 - 9 } & Number & $\mathbf{\%}$ & Number & $\%$ & Number & $\%$ & Number & $\%$ \\
\hline Direct Tweet Posting & 754 & $\% 61,05$ & 439 & $\% 55,22$ & 152 & $\% 65,23$ & 1345 & $\% 59,43$ \\
\hline Reply and Retweet & 62 & $\% 5,02$ & 12 & $\% 1,50$ & 6 & $\% 2,57$ & 80 & $\% 3,53$ \\
\hline URL & 317 & $\% 25,66$ & 247 & $\% 31,06$ & 40 & $\% 17,16$ & 604 & $\% 26,69$ \\
\hline Hashtag & 102 & $\% 8,25$ & 97 & $\% 12,22$ & 35 & $\% 15,04$ & 234 & $\% 10,34$ \\
\hline Total & 1235 & $\% 100$ & 795 & $\% 100$ & 233 & $\% 100$ & 2263 & $\% 100$ \\
\hline
\end{tabular}

One of the questions for which answers were sought within the scope of the study is about "How are digital game brands use the language of their Twitter accounts between October 1 and December 31, 2020". Thus, it will be possible to gain a general idea about how brands adapt to the dialog characteristics defined as two-way communication in their posts. In this direction, when it is reviewed how the brands benefit from the technical features of the Twitter channel; 754 (61.05\%) of the Sony Playstation brand, 439 (55.22\%) of the Microsoft Xbox brand, and 152 (65.23\%) of the Ubisoft brand, were seen to be direct tweets. This indicates that brands use Twitter mainly based on one-way information on issues related to communication applications. From this point of view, it can be stated that all three brands prioritize tweets that mobilize them and make them buy, rather than dialogue with followers.

It was observed that most of the shares of the brands included in the study included URLs. URL is short for Uniform Resource Locator. In its simplest form, URL is the name of internet addresses. It is possible to quickly find the resources sought through these addresses. When the URL usage of brands is examined; Some of the shares of the Microsoft Xbox, including 247 (31.06\%), 317 (25.66\%) of the Sony Playstation, and 40 (17.16\%) of the Ubisoft, contain URLs. Since Twitter is a medium that requires a limited number of characters, brands fill this gap by adding links to their internet addresses that contain extensive information on the subjects they share. It is seen that especially Microsoft Xbox and Sony Playstation share the link of their web pages to enable their followers to access detailed information on the subject. 
In addition to direct post sharing, Twitter adopts another dominant communication method that allows people to send private messages via direct messages, as is the case with most computer mediated communication. This feature, known as “@ reply”, allows traditional users to target a conversation or reference a specific user (Marwick \& Boyd, 2016, p. 112). In addition, when users share tweets with their own accounts, they can offer content to new viewers with the feature known as "Retweeting", which enables this tweet to become more widespread.

Examining the extent to which brands benefit from these features, it is seen that 62 $(5.02 \%)$ of the Sony Playstation, $12(1.5 \%)$ of the Microsoft Xbox and 6 (2.57\%) of the Ubisoft benefit from these features in their shares. This shows that brands use Twitter to share information rather than messaging with customers one-on-one and referencing a specific user.

Twitter can group speech acts under a certain topic with its "\#” (hashtag) feature. "Trendy topics" (TT) on the Twitter home page are determined by hashtags. Hashtags are an application that allows Twitter to use the technical features of Twitter to attract social attention and direct the public to a certain subject (Karataş \& Binark, 2016, p. 432).

Words play a key role in brand building; It can be said that reality belongs to the world of shapes, colours, textures and dimensions, and that it is possible to have a meaning in the human mind by sitting in a context. The mind gives meaning to visual reality with words (Ries \& Ries, 2003, p. 45). It can be said that Twitter's frequent use of words via hashtags is important for brand development. In this direction, when it is examined to what extent brands benefit from this application; Sony Playstation 102 (8.25\%), Microsoft Xbox 97 $(12.22 \%)$ and Ubisoft $35(15.04 \%)$ are seen to use hashtags in their shares.

Research findings show that brands benefit most from Twitter specifications in the direction of using "direct tweet posting", "URL", "hashtag", "reply and retweet" respectively. This information also includes the answer to "how the direction of communication is in the forms of topics shared with the tweets of digital game brands", the last of the questions that were sought for answers as part of the study. Twitter, in terms of its technical features, is a medium that allows both two-way and one-way communication. Twitter's replies and retweets are features that allow relatively two-way communication. Hashtag is an application that enables the followers to increase their awareness of a certain subject and their sympathy for the brand, and partly to establish close relationships with the users. Apart from these, direct tweet and the use of URLs are features that provide one-way information to users. Therefore, it is seen that the brands examined within the scope of the study generally prefer one-way communication styles. It can be said that brands adopt a one-sided monologue-based communication style towards their followers rather than developing a dialogue based on two-way communication with their followers.

\section{Conclusion}

Today, it is known that brands are in search of a new and different medium in which they can convey their messages. Because even though the possibilities offered by traditional media are diverse, they are limited and more costly than alternative channels. Moreover, due to the coexistence of numerous competitors in traditional channels, there is a message bombardment, and it gets harder to gain a foothold in the minds of customers. In this case, brands are looking for alternative channels where they can address their customers and establish close contact with them. One of the channels that brands evaluate in this 
sense is the rapidly growing social media platforms, especially with the development of the internet.

With this study, it is aimed to present an evaluation on the use of social media, which is frequently preferred by brands in recent years, in line with brand communication. In the implementation phase of the study, the tweets shared by Sony Playstation, Microsoft Xbox, and Ubisoft, which are digital game brands with the highest number of followers on Twitter, a social network, during the quarter between October 1, 2020 and December 31, 2020 were examined. In the reviews for the accounts of the brands on Twitter; It is seen that the Sony Playstation ranks first in terms of the number of tweets posted on the dates specified. It is followed by Microsoft Xbox and Ubisoft. When the subject contents of the total shares in the accounts of the brands are analysed; It is observed that brands generally share messages regarding sales incentive, campaigns and promotions, information, advice-wishes, news, publicity, activity and corporate issues.

When the distribution of the messages in the tweets sent according to their subjects is evaluated separately for each brand; In the last quarter of 2020, the shares of Sony Playstation are; It is seen that it is loaded with messages related to publicity, sales incentive, news, campaigns and promotions, activity, corporate, advice-wishes. The shares of the Microsoft Xbox, respectively; It is stated that it is related to sales incentive, campaigns and promotions, publicity, advice-wishes, news, activity, information, and corporate issues. The shares of the Ubisoft are respectively; It is seen that it is related to sales incentive, publicity, campaign and promotion, news, advice-wishes, activity, corporate and information. In short, all three brands shared messages mostly related to sales promotion. In these messages, which are presented enriched with images and links, it is seen that brands generally direct their customers to purchase. In the second place, publicity messages dominate. In these messages, it was seen that the brands introduced their products, especially with their technological aspects, in the quarter.

In examinations regarding the format and direction of the messages in the Twitter accounts of the brands; It is seen that brands mostly evaluate their shares as direct tweet. Then, it is observed that the brands' posts contain too many URLs. In addition, it is seen that brands partially benefit from the "hashtag" feature known as speech acts under a certain topic. However, it has been determined that brands make very little use of the Twitter media's features known as @reply and "retweeting", which allow two-way communication. In summary, it has been observed that the brands use the Twitter mostly based on one-way communication and information, and as an incentive and action to buy more. It is thought that brands do not care much about the two-way communication offered by the Twitter channel and do not take advantage of the technical features that allow two-way communication. At this point, it will make an important difference that digital game brands prefer a two-way approach in social media communication and communicate with users directly.

If we evaluate the findings in terms of marketing communication, it has been observed that digital game brands tend to focus on areas such as advertising and direct sales, but do not provide sufficient interaction with users on issues such as customer relations.

\section{Notlar}

1https://www.forbes.com/sites/niallmccarthy/2018/05/14/the-companies-making-the-most-from-video-gamesinfographic/?sh=350a9c6f6610 (accessed 1 January 2021) 
2 https://twitter.com/PlayStation/status/1337446799678771201 (accessed 5 January 2021)

3 https:/twitter.com/PlayStation/status/1337218401744408579 (accessed 5 January 2021)

4 https://twitter.com/PlayStation/status/1337133489817346049 (accessed 5 January 2021)

5 https://twitter.com/PlayStation/status/1339997607721091072 (accessed 5 January 2021)

6 https://twitter.com/PlayStation/status/1340120170891767812 (accessed 5 January 2021)

7 https://twitter.com/PlayStation/status/1337412226496540673 (accessed 5 January 2021)

8 https://twitter.com/PlayStation/status/1340386682332430337 (accessed 5 January 2021)

9 https://twitter.com/AskPlayStation/status/1339737360184078336 (accessed 5 January 2021)

10 https:/twitter.com/PlayStation/status/1339963765798920193 (accessed 5 January 2021)

11 https://twitter.com/PlayStation/status/1335954878368276481(accessed 5 January 2021)

12 https://twitter.com/PlayStation/status/1332021306842296321 (accessed 5 January 2021)

13 https://twitter.com/PlayStation/status/1337466692851687425(accessed 5 January 2021)

14 https://twitter.com/Microsoft/status/1341428399173218305 (accessed 10 January 2021)

15 https://twitter.com/Xbox/status/1340069332357947394 (accessed 10 January 2021)

16 https://twitter.com/Xbox/status/1339601325928009730 (accessed 10 January 2021)

17 https://twitter.com/unfoundation/status/1341136479188299782 (accessed 10 January 2021)

18 https:/twitter.com/CDCFound/status/1337424893755977731 (accessed 10 January 2021)

19 https://twitter.com/Xbox/status/1340114630719336449 (accessed 10 January 2021)

20 https://twitter.com/NintendoAmerica/status/1341081003771760643 (accessed 15 January 2021)

21 https://twitter.com/Ubisoft/status/1332334008198443008 (accessed 10 January 2021)

22 https://twitter.com/Ubisoft/status/1341428379183099907 (accessed 10 January 2021)

$23 \mathrm{https}: / /$ twitter.com/FenyxRising/status/1339616483928846336 (accessed 15 January 2021)

$24 \mathrm{https} / / /$ twitter.com/assassinscreed/status/1329516259654897665 (accessed 15 January 2021)

25 https://twitter.com/assassinscreed/status/1316393333305081858 (accessed 15 January 2021)

26 https://twitter.com/LifeatUbisoft/status/1318958486340993024 (accessed 15 January 2021)

27 https://twitter.com/Ubisoft/status/1341355659741319169 (accessed 15 January 2021)

\section{References}

Arruda, W. (2009). Brand Communication: The Three Cs. Thunderbird International Business Review, 51(5), 409-416. doi:https://doi.org/10.1002/tie.20279

Arvidsson, A. (2006). Brands: Meaning and Value in Media Culture. New York \& London: Routledge.

Bak, L., Madsen, A., \& Henrichsen, B. \&. (2012). Danskernes Kulturvaner. Copenhagen, Denmark: Danish Ministry of Culture.

Bayraktutan, G., Binark, M., Çomu, T., Doğu, B., İslamoğlu, G., \& Aydemir, A. (2013). Sosyal Medyada 2011 Genel Seçimleri Nicel-Nitel Arayüzey İncelemesi. Selçuk İletişim, $7(3), 5-29$.

Belk, R. W. (2013). Extended Self in a Digital World. Journal of Consumer Research, 40(3), 477-500. doi:https://doi.org/10.1086/671052

Bilgin, N. (2006). Sosyal Bilimlerde İçerik Analizi Teknikler ve Örnek Çalışmalar. Ankara: Siyasal Kitapevi. 
Binark, M., \& Sütçü, G. (2008). Dijital Oyun. İstanbul: Kalkedon Yayınları.

Buluş, B., \& Buluş, G. C. (2020). Kültür Endüstrisi Ürünü Olarak Dijital Oyunlar ve Dijital Ekonomi. Aksaray Üniversitesi Íktisadi ve İdari Bilimler Fakültesi Dergisi, 12(2), 1-6.

Cabras, I., Goumagias, N. D., Fernandes, K., Cowling, P., Li, F., Kudenko, D., ... Nucciarelli, A. (2017). Exploring survival rates of companies in the UK video-games industry: An empirical study. Technological Forecasting and Social Change(117), 305-314.

Castells, M. (2004). The Rise of the Network Society Information Age: Economy, Society and Culture Volume 1. West Sussex, UK: Wiley-Blackwell.

Cho, S., \& Huh, J. (2010). Content analysis of corporate blogs as a relationship management toolnull. Corporate Communications: An International Journal, 15(1), 30-48. doi:https://doi.org/.10.1108/13563281011016822

Çetin, S., \& Elmasoğlu, K. (2014). Politik Propaganda Aracı Olarak Sosyal Medya: Siyasilerin Gezi Parkı Olayları Esnasında Twitter Kullanım Pratikleri Üzerine Bir İnceleme. In S. Kavoğlu., Teoriden Uygulamaya Siyasal İletişim (pp. 223-238). Ankara: Nobel Yayınevi.

Davis, A. (2011). Rekabetçi başarı, markalaşma nasıl değer katar? (U. Mehter, Trans.) İstanbul: BrandAge Yayınları.

Feldwick, P. (2003). Brand Communications. In R. Clifton, \& J. Simmons, Brands and Branding (pp. 127-142). Lonra: The Economist Pasific Books.

Firat, A. F., \& Dholakia, N. (2006). Theoritical and Philosophical implications of postmodern debates: some challenges to modern marketing. Marketing Theory, $6(2), 123-162$.

Gandini, A. (2016). Digital Work: Self-Branding and Social Capital in The Freelance Knowledge Economy. Marketing Theory, 16(1), 123-143. doi:https://doi. org/10.1177/1470593115607942

Glass, Z. (2007). The effectiveness of product placement in video games. Journal of Interactive Advertising, 8(1), 23-32.

Grace, D., \& O'Cass, A. (2004). Examining service experiences and post-consumption evaluations. Journal of Services Marketing, 18(6), 450-461.

Gros, B. (2007). Digital Games in Education. Journal of Research on Technology in Education, 40(1), 23-38. doi:https://doi.org/10.1080/15391523.2007.10782494

Güz, N., Yegen, C., \& Yanık, H. (2016). New Media and Journalism in Turkey: A Comparative Analysis on Twitter Usage Practices of Yeni Şafak and Sözcü Newspapers. In I. D. Rocha, A. F. Planells, \& C. Singla, The International Conference on Integrated Journalism Education, Research and Innovation Proceedings (pp. 97313). Spain: Universitat Pompeu Fabra.

Iversen, M. S. (2016). Play and Productivity: The Constitution of Ageing Adults in Research on Digital Games. Games and Culture, 11(1-2), 28-52. doi:https://doi. org/10.1177/1555412014557541

Karataş, Ş., \& Binark, M. (2016). Yeni Medyada Yaratıcı Kültür: Troller ve Ürünleri 'Caps'ler. TRT Akademi Dijital Medya, 2(1), 426-448. 
Ki, E. J., \& Hon, L. C. (2006). Relationship maintenance strategies on Fortune 500 company web sites. Journal of Communication Management,, 10(1), 27-43. doi:https://doi.org/10.1108/13632540610646355

Kitchen, P. J., \& Schultz, D. E. (2003). Integrated Corporate and Product Brand Communication. Advances in Competitiveness Research, 11(1), 66-86.

Labrecque, L., Ereni, M., \& Milne, G. (2011). Online Personal Branding: Processes, Challenges, and Implications. Journal of Interactive Marketing, 25(1), 37-50. doi:https://doi.org/10.1016/j.\%20intmar.2010.09.002

Lazar, J. (2009). İletişim Bilimi. (C. Anık, Trans.) Ankara: Vadi Yayınları.

Lipsman, A., Mudd, G., Rich, M., \& Burch, S. (2012). The Power of Like. Journal of Advertising Research, 52, 40-52. doi:http://dx.doi.org/10.2501/JAR-52-1-040-052

Mangold, W. G., \& Faulds, D. J. (2009). Social media: The new hybrid element of the promotion mix. Business Horizons, 52, 357-365. doi:http://dx.doi.org/10.1016/j. bushor.2009.03.002

Marwick, A. E., \& Boyd, D. (2016). I tweet honestly, I tweet passionately: Twitter users, context collapse, and the imagined audience. New media \& society, 13(1), 114-133. doi:https://doi.org/10.1177/1461444810365313

Martí-Parreño, J., Bermejo-Berros, J., \& Aldás-Manzano, J. (2017). Product placement in video games: The effect of brand familiarity and repetition on consumers' memory. Journal of Interactive Marketing, 38, 55-63.

Mattelart, A. (1995). Beyin İğfal Şebekesi Uluslararası Reklamcılık. (I. Gürbüz, Trans.) İstanbul: Ayrıntı Yayınları.

Miles, M. B., \& Huberman, A. M. (1994). Qualitative data analysis: An expanded sourcebook. CA: Sage.

Mosco, V. (1988). Introduction: Information in the Pay-Per Society. In V. Mosco, \& J. M. Wasko, Political Economy of Information (pp. 3-26). Wisconsin: The University of Wisconsin Press.

Nelson, M. R. (2002). Recall of brand placements in computer/video games. Journal of advertising research, 42(2), 80-92.

Özgen, Ö., \& Elmasoğlu, K. (2016). Sosyal Medya ve Marka İletişimi: Havayolu Şirketlerinin Twitter Kullanımına Yönelik Bir Araştırma. İletişim Kuram ve Araştırma Dergisi, 43, 181-202.

Öztürk, M. C. (2015). Sosyal Medya ve Kurumsal İletişim. In M. C. Öztürk, Dijital İletişim ve Yeni Medya (pp. 120-152). Eskişehir: Anadolu Üniversitesi Yayınları.

Papatya, N. (2006). İşletmelerde Rekabetçi Zekanın Değișen Yüzü: Girişimci Pazarlama. Pİ-Pazarlama iletişim Kültür Dergisi-Mediacat, 5(16), 45-59.

Peltekoğlu, F. (2009). Halkla İlişkiler Nedir? İstanbul: Beta Yayıncılık.

Pratchett, R. (2005). Gamers in the UK, Digital play, Digital Lifestyles. BBC New Media \& Technology: Creative Research and Development Department. Retrieved from https://crystaltips.typepad.com/wonderland/files/bbc_uk_games_research_2005. pdf

Ries, A., \& Ries, L. (2003). The 22 Immutable Laws of Branding. New York: HarperCollins. 
Schor, J. (2004). Born to Buy: The Commercialized Child and The New Consumer Culture. New York: Scribner.

Stephen, A. (2016). The Role of Digital and Social Media Marketing in Consumer Behavior. Current Opinion in Psychology, 10(1), 17-21. doi:https://doi. org/10.1016/j.copsyc.2015.10.016

Taecharungroj, V. (2016). Starbucks' marketing communications strategy on Twitter. Journal of Marketing Communications, 23(6), 552-571. doi:http://dx.doi.org/10.10 80/13527266.2016.1138139

Tafesse, W. (2015). Content strategies and audience response on Facebook brand pages. Marketing Intelligence \& Planning, 33, 927-943. doi:http://dx.doi.org/10.1108/ MIP-07-2014-0135

Tafesse, W. (2016). An experiential model of consumer engagement in social media. Journal of Product \& Brand Management, 25, 424-434. doi:https://doi. org/10.1108/JPBM-05-2015-0879

Tafesse, W., \& Wien, A. (2017). A framework for categorizing social media posts. Cogent Business and Management, 4, 1-22. doi:http://dx.doi.org/10.1080/23311975.201 7.1284390

Temporal, P. (2010). Advanced Brand Management: Managing Brands in a Changing World. New York: Wiley.

Tosun, N. B. (2010). İletişim Temelli Marka Yönetimi. İstanbul: Beta basım.

Vassallo, A. J., Bridget, K., Zhang, L., Wang, Z., Young, S., \& Freeman, B. (2018). Junk Food Marketing on Instagram: Content Analysis. JMIR Public Heal Surveill, 2(4), 1-11. doi:https://doi.org/10.2196/publichealth.9594

Vries, L., Gensler, S., \& Leeflang, P. S. (2012). Popularity of Brand Posts on Brand Fan Pages: An Investigation of the Effects of Social Media Marketing. Journal of Interactive Marketing, 26(2), 83-91.

Wattanacharoensil, W., \& Schuckert, M. (2015). How global airports engage social media users: A study of Facebook use and its role in stakeholder communication. Journal of Travel \& Tourism Marketing, 32(6), 656-676. doi:http://dx.doi. org/10.1080/10548408.\%202014.955245

Zaglia, M. E. (2013). Brand communities embedded in social networks. Journal of business research, 66(2), 216-223. doi:https://doi.org/10.1016/j. jbusres.2012.07.015 


\title{
Dijital Oyun Markalarının Twitter Kullanım Pratikleri
}

\author{
Fatih Söğüt (Asst. Prof. Dr.)
}

\section{Genişletilmiş Özet}

Günümüzde klasik medyanın popülaritesini sonlandıran; sosyal medya, birbirinden bağımsız olarak gelişen ve kullanıcıların kendi içeriklerini yansıtmalarına ve başkalarıyla paylaşmalarına olanak tanıyan çevrimiçi uygulamalar olarak tanımlanmaktadır. Nitekim bu tür medyada kullanıcılar ve paylaşanlar arasında teknolojik gelişmelere dayalı karşılıklı bir etkileşim söz konusudur ve bu etkileșimin temeli teknolojideki gelişmeler ve Web 2.0 teknolojisinin gelişmesidir. Sosyal medya, özellikle son yıllarda tüketicilerin internet kullanımının artması ve sosyal medya kanallarında geçirdikleri zamanın artmasıyla markalar için önemli bir marka iletişim kanalı haline geldi. Sosyal medya kanalları olarak listelenmiş; bloglar, mikrobloglar, sosyal ağlar ve forumlar sayesinde markalar, müşterilerine birçok kanaldan hitap edebilir. Benzer şekilde, bireyler artık bir karar vermeden önce blogger önerilerini dinliyor ve sosyal ağlardaki bağlantıları gözden geçiriyor. Bu nedenle sosyal medya, marka uzmanları ve pazarlamacılar için çok önemli bir platformdur. Markaların hedef kitlesine, kullanım alışkanlıklarına, ilgi alanlarına, şikayetlerine, ihtiyaçlarına kısacası aradıkları her şeye sosyal medya üzerinden ulaşmaları mümkündür.

Günümüzde üretim ve tedarikte dijitalleşmeye yönelik üretim çıktıları farklı şekillerde ortaya çıkmaktadır. İletişim platformlarında farklı platformlar arasında kurulan yakınlık, üretim ve tüketim kanallarının sağlıklı işlemesi için farklı kültürel öğeler içeren yapıları ortaya çıkarmaktadır. Ayrıca iletişim kanalı içeriğinin özgün yapıları, tüketim sürecinde birbirini tamamlayan yapılar oluşturmaktadır. Bir oyun türü olarak dijital oyunlar, bilgisayar oyunları, video oyunları ve elektronik oyunlar gibi kavramlar ve kültürel öğelerle 1980'lerin ortalarından itibaren ortaya çıktı ve gelişmeye devam etti. Ancak dijital oyun tanımı literatürde 2000'li yılların ortalarından itibaren sıklıkla kullanılmaktadır. Dijital oyunların tanımında birbirinden farklı her türlü atari oyunları, bilgisayar oyunları, konsol oyunları ve mobil oyunlar vardır.

Günümüzün başlıca kültürel endüstri araçları olan televizyon, radyo, kitaplar, gazeteler, dergiler, filmler ve müzik gibi geleneksel medya endüstrilerinin yanı sira internet ve dijital oyunlar gibi yeni medya endüstrilerini de içerir. Bu tür metaların en belirleyici özelliği, bu türlerin farklı kültürel kod ve kalıplardan oluşmasıdır. İletişime dayalı tüketim süreçleri incelendiğinde ve bu süreçler aktör açısından değerlendirildiğinde kapitalist üretim ilişkilerine dikkat çekmek gerekiyor. Gerçekte, dijital oyuncuların kapitalist üretim ilişkilerini yeniden üretmedeki rolü, geleneksel medya izleyici tartışmalarından farklıdır.

$\mathrm{Bu}$ çalışmanın temel amacı, marka iletişimi açısından sosyal medya kullanımını incelemektir. $\mathrm{Bu}$ çalışmada araştırma alanı olarak tweet adı verilen maksimum 140 karakterle metin yazma imkânı sunan bir sosyal ă̆ olan "Twitter" belirlendi. Twitter, günümüzde oldukça sık kullanılan popüler bir sosyal ağ ve mikroblog sitesidir. Twitter, hayat ve gündem hakkındaki fikirlerden bağlantılara ve anlık gelişmelere kadar sürekli güncellenen bir zaman çizelgesi oluşturarak kullanıcıları "ne yapıyorsun" sorusunu yanıtlamaya teşvik eder. Twitter, kullanıcılarının kendi erişim alanlarında "takip etmeleri" için kendi Twitter hesaplarını seçmelerine ve her birinin kendi "takipçisine" sahip olmasına olanak tanıyan bir ortamdır. 
Twitter gibi sosyal ağ siteleri, markaların kullanıcıları ile iletişim kurmak için sıklıkla kullandıkları kanallar arasında yer alıyor. Markalar, ürünleri ve kampanyaları hakkında sosyal ağ siteleri aracılığıyla bilgi aktarabilir ve kullanıcıları ile diyalojik iletişim geliştirebilirler. Marka bilgilerini aktarmak veya yorumlara yanıt vermek için kullanılabilen Twitter'ın marka imajının oluşmasına katkı sağladığı düşünülmektedir. Twitter aracılığıyla, marka yöneticileri yalnızca müşterilerin ve potansiyel tüketicilerin ne hakkında konuştuklarını değil, daha da önemlisi, kullandıkları kelimeler ve ifadelerle kendilerini nasıl ifade ettiklerini anlayabilirler. Bu verilerle daha iyi ürünler, hizmetler ve iletişim mesajları tasarlanabilir. Ayrıca, promosyonlar gibi markalaşma etkinlikleri için "hashtag" adı verilen etiketler oluşturarak, marka yöneticileri, tüketicileri belirli bir konu hakkında tartışmaya ve geri bildirim vermeye, markasını satın alan kişilerin konuşmalarını yönetmeye, hedef pazardaki fikir liderlerini belirlemeye teşvik edebilir.

$\mathrm{Bu}$ çalışmada markaların Twitter'da sosyal medyayı nasıl kullandığına dair bir değerlendirme yapılması ve konu ile ilgili literatüre katkı sağlanması amaçlanmıştır. $\mathrm{Bu}$ hedef doğrultusunda araştırma kapsamında dünyada dijital oyun sektöründe faaliyet gösteren Sony Computer Entertainment, Ubisoft ve Microsoft şirketleri çalışma alanı olarak seçildi. Bu şirketler forbes online web sitesinin en değerli 10 oyun şirketi arasındadır. En değerli oyun şirketleri arasında bu şirketlere bağlı markalar en yüksek twitter takipçisine sahip oldukları için seçilmiştir.

Belirtilen tarihler arasında Playstation markası için @PlayStation, https://twitter.com/ PlayStation; @Xbox, https://twitter.com/Xbox Xbox markası için; Ubisoft markası için @Ubisoft, https://twitter.com/Ubisoft adresleri incelendi. Her üç markanın da Twitter hesaplarında bulunan toplam 2263 tweet 1-15 Ocak 2021 tarihleri arasında geriye dönük tarandı ve içerik analizi ile değerlendirildi. 1 Ekim 2020- 31 Aralık 2020 dönemini kapsayan 3 aylık dönemde- Ekim, Kasım ve Aralık- seçilen markaların yayınladıkları tweetler rastgele belirlendi.

Markaların Twitter hesabı üzerinden yapılan incelemelerde; Sony Playstation'ın belirtilen tarihlerde atılan tweet sayısı açısından ilk sırada yer aldığı görülüyor. Bunu Microsoft Xbox ve Ubisoft takip ediyor. Markaların hesaplarında yer alan toplam payların konu içerikleri incelendiğinde; Markaların genel olarak satış teşviki, kampanya ve promosyonlar, bilgiler, tavsiye-temenniler, haberler, tanitım, etkinlik ve kurumsal konularla ilgili mesajlar paylaştığı görülmektedir. Konularına göre gönderilen tweetlerdeki mesajların dağılımı her marka için ayrı ayrı değerlendirildiğinde; 2020'nin son çeyreğinde Sony Playstation'ın hesabı; tanıtım, satış teşviki, haberler, kampanyalar ve promosyonlar, etkinlik, kurumsal, tavsiye-dilekler ile ilgili mesajlarla dolu olduğu görülmektedir. Microsoft Xbox hesabı sırasıyla; satış teşviki, kampanya ve promosyonlar, tanıtım, tavsiye-temenniler, haberler, etkinlikler, bilgiler ve kurumsal konularla ilgili paylaşımlar bulunmaktadır. Ubisoft'un hesabı sırasıyla; satış teşviki, tanıtım, kampanya ve tanıtım, haberler, tavsiye-temenniler, etkinlik, kurumsal ve bilgilendirme ile ilgili olduğu görülmektedir. Kısacası, her üç marka da çoğunlukla satış promosyonuyla ilgili mesajlar paylaşmıştır. Görsellerle ve linklerle zenginleștirilerek sunulan bu mesajlarda, markaların genel olarak müșterilerini satın almaya yönlendirdiği görülmektedir. İkincisi, tanıtım mesajları hakimdir. Bu mesajlarda markaların ürünlerini özellikle teknolojik yönleriyle tanıttığı görüldü. Markaların Twitter hesaplarındaki mesajların formatı ve yönü ile ilgili incelemelerde; Markaların daha çok paylaşımlarını direkt tweet olarak değerlendirdikleri görülmüştür. Ardından markaların gönderilerinin çok fazla URL içerdiği gözlemlendi. Ayrıca markaların belirli bir konu altındaki konuşma eylemleri olarak bilinen "hashtag" özelliğinden kısmen yararlandığ 
görülüyor. Ancak markaların Twitter medyasının iki yönlü iletişime imkân veren "@reply” ve "retweeting" olarak bilinen özelliklerinden çok az yararlandıkları tespit edilmiştir. Özetle, markaların Twitter'ı daha çok tek yönlü iletişim ve bilgilendirmeye dayalı, daha fazlasını satın almak için bir teşvik ve eylem aracı olarak kullandıkları görülmüştür. Markaların Twitter kanalının sunduğu çift yönlü iletişimi pek önemsemediği ve iki yönlü iletişime imkân veren teknik özelliklerden yararlanmadığı tespit edilmiştir.

Anahtar Kelimeler: Microsoft Xbox, Twitter, Ubisoft, Marka İletişimi, Sony PlayStation.

Bu makale intihal tespit yazııımlarıyla taranmıştır. Intihal tespit edilmemiştir.

This article has been scanned by plagiarism detection softwares. No plagiarism detected.

Bu çalışmada "Yükseköğretim Kurumları Bilimsel Araştırma ve Yayın Etiği Yönergesi" kapsamında uyulması belirtilen kurallara uyulmuştur.

In this study, the rules stated in the "Higher Education Institutions Scientific Research and Publication Ethics Directive" were followed.

Araştırma tek bir yazar tarafından yürütülmüştür.

The research was conducted by a single author.

Çalışma kapsamında herhangi bir kurum veya kişi ile çıkar çatışması bulunmamaktadır.

There is no conflict of interest with any institution or person within the scope of the study. 